UDC 631.16:631.5-1/2:635.62

(c) 2016

\title{
Economic assessment of elements of technology of cultivation of grades of muscat pumpkin in Forest-steppe
}

\author{
V. Hareba, \\ Corresponding Member of the National Academy of Sciences of Ukraine, Doctor of Agricultural \\ Sciences \\ V. Kokoiko \\ National University of Bioresources and Natural Resources of Ukraine
}

The purpose. To assess economically elements of technique of cultivation of muscat pumpkin in conditions of Forest-steppe of Ukraine. Methods. Field, laboratory-analytical, mathematical and statistical. Results. The most economically favourable grades, regulators of growth and schemes of disposition of plants are revealed. Conclusions. Economically the most favourable for Forest-steppe of Ukraine elements of techniques of cultivation of muscat pumpkin on low humus and sandy loam typical chernozem are: grades Dyvo and Dolia, treatment of seeds and plants of grade Yanin with preparation Biolan, use of scheme of disposition of plants 1,4x1,4 m on grade Dolia.

Key words: pumpkin, Cucurbita moschata Duch. Ex Poir, grade, schemes of sowing, regulators of growth of plants, cost price, profitability.

\section{Introduction}

One of the high yield vegetables is squash $[1,2,5,6]$. The one grown by American Norman Halater weighed $278 \mathrm{~kg}$ and was listed in the Guinness Book of Records [10,12]. Thanks to the harmonious combination of vitamins, enzymes, and proteins, it is easily absorbed by the body, that's why it's considered to be a valuable product for healthy, invalid and protective diet $[1,5,6,12]$.

According to the rules of the Academy of Medical Sciences, the annual intake of melons must be at least $30 \mathrm{~kg}$ per person [1, 2, 6]. Pulp of fruits contains $70-93 \%$ of water, and $6-30 \%$ of dry matter, which in its turn contains $1.5-15 \%$ of sugar, $4-23 \%$ of fat, up to $24 \%$ of starch, $0.3-1.4$ of ash, up to $1.4 \%$ of pectin, $25-40 \mathrm{mg}$ per $100 \mathrm{~g}$ of vitamin $\mathrm{C}$, and 2-28 $\mathrm{mg}$ per $100 \mathrm{~g}$ of carotene $[1,2,11,12]$. The basis of nutritional value is the presence of sugars, starch, fiber and carotene $[6,9,12]$. Caloric value is not high - in $100 \mathrm{~g}$ of product there are 29 calories [1.10]. It is used in traditional medicine to treat cardiovascular diseases, stomach ulcers, etc. $[1,6,11]$. The fruits are well preserved during the winter providing population with vitamins in the winter period [6,9]. For efficient proceedings of any growing technology elements it is essential an economic assessment which will determine the feasibility of its use. The main indicators of economic evaluation are cost per unit, operating profit and profitability [3].

\section{Analysis of recent research and publications}

Despite the value of China squash, the scientific literature provides little information on the economic assessment of elements of its growing technology. Most studies cover the selection of sowing terms and of plant layouts, but the assessment of varieties and plant growth regulators is not provided [7,12]. V. I. Ovcharuk and V. F. Lendel found that in Western Forest-Steppe zone of Ukraine for the plant layout $0.7 \times 1.4 \mathrm{~m}$ it was obtained the highest yield (36.5 t/ha) and profitability (156.5\%). Economic evaluation of the elements of China squash growing technology is not studied enough in terms of Forest-Steppe zone of Ukraine, that's why this issue is topical.

The aim of research is to conduct an economic evaluation of the elements of China squash growing technology in terms of Forest-Steppe zone of Ukraine.

\section{Material and methods of research}

The study was conducted during the 2013-2015 on the experimental field of the Department of Horticulture in Separated Subdivision of National University of Life and Environmental Sciences of Ukraine "Agronomic Research Station" in typical low-humic light-loamy black soil according to particlesize distribution. The reaction of soil medium is $\mathrm{pH}$ 7.5. Content of absorbed bases amount is high -21.1 $\mathrm{mEq} / 100 \mathrm{~g}$ soil. According to Grishin L. A. and Orlov D. S., humus amount was $-4.07 \%$ (high availability). Easy hydrolysed nitrogen (by Kornfild's method) contains $196 \mathrm{mg} / \mathrm{kg}$; labile phosphorus (by Chirikov's method) $-60 \mathrm{mg} / \mathrm{kg}$ (medium availability); exchange potassium (by Chirikov's method) - 166 $\mathrm{mg} / \mathrm{kg}$ soil (increased). Groundwater lies at a depth of 2-5 m [4]. 
During the research, meteorological conditions differed; the most favorable were 2013-2014 when it was observed the largest rainfall during the growing season $(466.6-516.7 \mathrm{~mm})$, which is by $124.3-$ $174.4 \mathrm{~mm}$ higher than in long-term data. Significant moisture deficit $(139.1 \mathrm{~mm})$ was observed in 2015 , when the rainfall was by $203.2 \mathrm{~mm}$ less when compared to the long-term data.

They were studied China squash varieties (Cucurbita moschata Duch. Ex Poir.) - Dolia (the control), Yanina, Hileia, Dyvo. The experiment was laid out using the method of research in horticulture and melon growing. [7] The effect of plant growth regulators was studied in varieties Dolia (the control) and Yanina. They were studied preparations emistim C, biolan and stympo. The study included the treatment of seeds before sowing with $0.001 \%$ solution of preparations with exposure of 16 hours and treatment of plants during the vegetation season in two phenological phases: two true leaves, and during budding with $0.0001 \%$ solution of preparations, according to the manufacturer's recommendations. For the control it was used the treatment with water. The test was conducted in accordance with the "Methodology for testing and use of pesticides" (2001) [8].

Effect of plant layout was studied in Dolia variety. According to the ISO 5045:2008 for the control it was used the layout $1.4 \times 1.4 \mathrm{~m}$ (5.1 thousand plants per hectare). In terms of increasing the distance between plants up to 1.7-2.0 m they were studied the layouts $1.4 \times 1.7$ and $1.4 \times 2.0 \mathrm{~m}$, and the in terms of reduction down to $0.8-1.1 \mathrm{~m}$ - the layouts $1.4 \times 1.1$ and $1.4 \times 0.8 \mathrm{~m}$ respectively. The plant density was 3.5-9.0 thousand plants per hectare. The experiment was laid down according to the methodology of research in horticulture and melon growing [7]. Economic efficiency of cultivation of China squash varieties was calculated on the bases of the full cost for a typical technological card of pumpkin growing. The calculations are made at prices in 2015.

\section{Results and discussion}

Growing of China squash during 2013-2015 was economically beneficial due to high productivity of the varieties of this species. At the end of 2015, the wholesale price of standard China squash fruit ranged from 1 to $2 \mathrm{UAH} / \mathrm{kg}$, for economic evaluation it was taken the minimum price of $1 \mathrm{UAH} / \mathrm{kg}$, nonstandard fruits were estimated at cost.

The value of production costs was caused by higher expenditure on hand weeding and harvesting. Thus, in terms of high yields the costs were raising, at that the unit costs decreased; the similar trend was observed according to profitability (Table 1).

Table 1. Economic evaluation of China squash growing under generally accepted technology (average for 2013-2015).

\begin{tabular}{|l|l|l|l|l|l|l|}
\hline Variety & Yield, t/ha & $\begin{array}{l}\text { Farm } \\
\text { inputs, } \\
\text { UAH/ha }\end{array}$ & $\begin{array}{l}\text { Cost of } \\
\text { production, } \\
\text { UAH/t }\end{array}$ & $\begin{array}{l}\text { Costs of gross } \\
\text { product from } \\
\text { 1ha, UAH }\end{array}$ & $\begin{array}{l}\text { Operating profit, } \\
\text { UAH/ha }\end{array}$ & $\begin{array}{l}\text { Profitability } \\
\text { level,\% }\end{array}$ \\
\hline Dolia & 34.3 & 14286.1 & 416.5 & 34300 & 20013.9 & 140.1 \\
\hline Yanina & 29.3 & 13881.1 & 473.8 & 29300 & 15418.9 & 111.1 \\
\hline Hileia & 23.2 & 13387.0 & 577.0 & 23200 & 9813.0 & 73.3 \\
\hline Dyvo & 36.3 & 14448.1 & 398.0 & 36300 & 21851.9 & 151.2 \\
\hline
\end{tabular}

Significant production costs $(14,448.1$ and $14,286.1 \mathrm{UAH} / \mathrm{ha})$ were fixed in the varieties Dyvo and Dolia. However, the cost of production was the lowest for them (398.0 and $416.5 \mathrm{UAH} / \mathrm{t}$ ) when compared to the other variants of the experiment. Despite minor production costs $(13,387.013,881.1$ and $\mathrm{UAH} / \mathrm{ha})$ when growing varieties Hileia and Yanina, unit production cost for them was by 57.3 and $160.5 \mathrm{UAH} / \mathrm{t}$ lower than for Dolia variety (the control).

Economically advantageous was growing varieties Dyvo and Dolia that showed relatively high net income $21,851.9$ and $20,013.9 \mathrm{UAH} / \mathrm{ha}$, and the profitability of 151.2 and $140.1 \%$. The lowest net income of $9813.0 \mathrm{UAH} / \mathrm{ha}$ and profitability of $73.3 \%$ was observed in Hileia variety that was by $10200.9 \mathrm{UAH}$ and $66.8 \%$ lower than in the control.

The use of plant growth regulators (PGR) during the China squash varieties growing increased yields and reduced costs of the resulting product (Table 2). 
Table 2. Economic evaluation of the use of plant growth regulators for the China squash varieties growing (average for 2013-2015).

\begin{tabular}{|l|l|l|l|l|l|l|}
\hline Variety & Yield, t/ha & $\begin{array}{l}\text { Farm inputs, } \\
\text { UAH/ha }\end{array}$ & $\begin{array}{l}\text { Cost of } \\
\text { production, } \\
\text { UAH/t }\end{array}$ & $\begin{array}{l}\text { Costs of } \\
\text { gross } \\
\text { product from } \\
\text { 1ha, UAH }\end{array}$ & $\begin{array}{l}\text { Operating } \\
\text { profit, } \\
\text { UAH/ha }\end{array}$ & $\begin{array}{l}\text { Profitability } \\
\text { level,\% }\end{array}$ \\
\hline Dolia (c) & \multicolumn{7}{|l|}{} \\
\hline Water (c) & 38.5 & 14824.1 & 385.0 & 38500 & 23675.9 & 159.7 \\
\hline Biolan & 31.1 & 14449.1 & 464.6 & 31100 & 16650.9 & 115.2 \\
\hline Emistym C & 36.5 & 14806.1 & 405.6 & 36500 & 21693.9 & 146.5 \\
\hline Stympo & 30.7 & 14434.7 & 470.2 & 30700 & 16265.3 & 112.7 \\
\hline Yanina & 42.0 & 15107.6 & 359.7 & 42000 & 26892.4 & 178.0 \\
\hline Water (c) & 46.3 & 15680.3 & 338.7 & 46300 & 30619.7 & 195.3 \\
\hline Biolan & 15494.6 & 347.4 & 44600 & 29105.4 & 187.8 \\
\hline Emistym C & 44.6 & 15082.7 & 389.7 & 38700 & 23617.3 & 156.6 \\
\hline Stympo & 38.7 &
\end{tabular}

Thus, Dolia variety was not significantly influenced by growth regulators in terms of improving economic efficiency. In particular, the highest productivity $(38.5 \mathrm{t} / \mathrm{ha})$ and production costs $(14,824.1$ $\mathrm{UAH} / \mathrm{ha}$ ) were obtained in terms of treatment with water (the control), the cost of the resulting product at that was $(385.0 \mathrm{UAH} / \mathrm{t})$. In the above mentioned variant it was observed the highest operating profit $(23,675.9$ and $21,693.9 \mathrm{UAH} / \mathrm{ha}$ ) and profitability (159.7 and $146.5 \%)$.

In Yanina variety the high yield (46,3t / ha) and production costs $(15,680.3 \mathrm{UAH} / \mathrm{ha})$ were observed in terms of treating with preparation biolan. Cost of production was the lowest (338.7 t/ha), and operating profit $(30,619.7 \mathrm{UAH} / \mathrm{ha})$. The level of profitability at that increased up to $195.3 \%$, which is by $17.3 \%$ more than for the control. Use of the preparation stympo led to lower production costs $(15,082.7 \mathrm{UAH} / \mathrm{ha})$, but due to low yields ( $38.7 \mathrm{t} / \mathrm{ha}$ ) the cost of production increased by $30 \mathrm{UAH} / \mathrm{t}$, compared to the treatment with water (the control). In addition, this variant received the lowest net income (UAH 23,617.3) and profitability (156.6\%), which is by UAH 3,275.1 and $21.4 \%$ less than for the control.

Plant layouts affected the economic efficiency of China squash varieties growing. The value of production costs depended not only on the cost of hand weeding and harvesting, but also on the layout of plants. Thus, reducing the distance between plants increased need for seeds, and increasing - reduced (Table 3).

Table 3. Economic evaluation of China squash variety Dolia depending on the layout of plants (average for 2013-2015)

\begin{tabular}{|l|l|l|l|l|l|l|}
\hline $\begin{array}{l}\text { Plant layout, } \\
\mathrm{m}\end{array}$ & Yield t/ha & $\begin{array}{l}\text { Production } \\
\text { costs, } \\
\text { UAH/ha }\end{array}$ & $\begin{array}{l}\text { Cost of } \\
\text { production, } \\
\text { UAH/t }\end{array}$ & $\begin{array}{l}\text { Costs of } \\
\text { gross } \\
\text { product from } \\
\text { 1ha, UAH }\end{array}$ & $\begin{array}{l}\text { Operating } \\
\text { profit, } \\
\text { UAH/ha }\end{array}$ & $\begin{array}{l}\text { Profitability } \\
\text { level,\% }\end{array}$ \\
\hline $1.4 \times 2.0$ & 23.3 & 13095.1 & 562.0 & 23300 & 10204.9 & 77.9 \\
\hline $1.4 \times 1.7$ & 25.1 & 13390.9 & 533.5 & 25100 & 11709.1 & 87.4 \\
\hline $1.4 \times 1.4(\kappa)$ & 38.2 & 14602.0 & 382.3 & 38200 & 23598.0 & 161.6 \\
\hline $1.4 \times 1.1$ & 35.7 & 14699.5 & 411.7 & 35700 & 21000.5 & 142.8 \\
\hline $1.4 \times 0.8$ & 33.0 & 15080.8 & 457.0 & 33000 & 17919.2 & 135.5 \\
\hline
\end{tabular}

In Dolia variety significant production costs were found under plant layouts $1.4 \times 0.8 \mathrm{~m}$ and $1.4 \times 1.1 \mathrm{~m}$ respectively $15,080.8$ and $14,699.5 \mathrm{UAH} / \mathrm{ha}$. The highest yield $(38.2 \mathrm{t} / \mathrm{ha})$ was obtained in variant $1.4 \mathrm{x}$ $1.4 \mathrm{~m}$ (the control). At that unit cost was the lowest (382.3 $\mathrm{UAH} / \mathrm{t})$, and operating profit $(23,598.0 \mathrm{UAH})$ was the highest. The level of profitability increased up to $161.6 \%$. Somewhat lower $(13,520.5$ and $12,916.9 \mathrm{UAH}$ ) expenses were characteristic for plant layouts $1.4 \times 1.7$ and $1.4 \times 2.0 \mathrm{~m}$, but the unit cost exceeded the control by179.7 and $151.2 \mathrm{UAH} / \mathrm{t}$. The use of plant layout $1.4 \times 1.4 \mathrm{~m}$ led to increased productivity $(1.7 \mathrm{t} / \mathrm{ha})$, and profitability $(5.1 \%)$ when compared to the previous studies by V. I. Ovcharuk and V. F. Lendel. 


\section{Conclusions}

The most cost-effective elements of technology (the selection of varieties, plant growth regulators and layout of plants) of China squash growing typical low-humic light-loamy black soil for Forest-Steppe zone of Ukraine appeared to be varieties Dyvo and Dolia which demostrated the highest yield 34.3-36.3 t/ha, operating profit 20,013.9-21,851.9 UAH/ha and profitability 140.1-151.2\%.

In terms of treating seeds of Yanina variety with preparation biolan, it was obtained high yield 46.3 t/ha, operating profit $30,619.7 \mathrm{UAH} / \mathrm{t}$, and profitability of $195.3 \%$. In terms of growing variety Dolia the use of the studied preparations led to decrease in yield and was not economically viable. The use of plant layout $1.4 \times 1.4 \mathrm{~m}$ in Dolia variety ensured high yield of $38.2 \mathrm{t} / \mathrm{ha}$, operating profit of 23,598.0 UAH/t, and profitability of $161.6 \%$.

\section{Bibliography}

1. Gourds in preventive nutrition / V. A. Lymar, Yu.G. Grigorov, A. O. Lymar [et al.]. - Kherson: Ailanthus, 2011. $-252 \mathrm{p}$.

2. Bilenko V. H. Healing pumpkin / V. H. Bilenko // Nassinnytstvo. - 2010. - № 10. - P. 26-27.

3. Hryzenkova Z. I. Energy assessment of costs for growing vegetables / Z. I. Hryzenkova, O. M. Honcharov, R. V. Levina // Horticulture and melon growing. - 1996. - № 41. - P. 9-13.

4. Dolgov S. I. Agrophysical methods of soil research / S. I. Dolgov. - M .: Kolos, 1968. -402 p.

5. Khareba V. V., Kokoiko V. V. Use of natural plant growth regulators (PGR) in China squash growing technologies (Cucurbita moschata Duch. Ex Poir) / V. V. Khareba, V. V. Kokoiko / - Horticulture and Melon Growing: mizhvid . temat. nauk. zb. - Kh., 2015. - Vol. 61. - P. 320-327.

6. Lymar O. A. Melon growing - a promising branch / V. A. Lymar // Bulletin of Agricultural Science. 2006. - № 12. - P. 43-47.

7. Methods of research in horticulture and melon growing / Ed. G. L. Bondarenko, K.I. Yakovenko. Kharkiv: Osnova, 2001. $-370 \mathrm{p}$.

8. Methods of testing and use of pesticides / [Trybel S. O., Sigariova D. D., Sekun M.P. et al.] Ed. S. O. Trybel. - K .: Svit, 2001. - 448 p.

9. Agbagwa I. O. The value of morpho-anatomical features in the systematics of Cucurbita L. (Cucurbitaceae) species in Nigeria. / I. O. Agbagwa., B. C. Ndukwu // - Afr. J Biotechnol. 2004. - № 3: 541-546.

10. FAO Production Yerbook. - Roome, 2002. Vol.55. - 416p.

11. Ferriol M. Pumpkin and winter squash. In: Vegetables I (edited by J. Prohens \& F. Nuez) / M. Ferriol, B. Pico. - New York: Springer. 2008. - P 317-349.

12. Wolford Ron. Pumpkins and More / Ron Wolford and Drusilla Banks.-University of Illinois Extension. -19 Feb. 2008. -12 p. 